\title{
Pengaruh Islamic Corporate Identity (ICI) terhadap Kinerja Bank Syariah di Indonesia
}

\author{
Eka Laily Romadhani \\ Sekolah Tinggi Ekonomi Islam (STEI) Yogyakarta \\ Email: ekalailyromadhani@gmail.com \\ Rofiul Wahyudi \\ Sekolah Tinggi Ekonomi Islam (STEI) Yogyakarta \\ Email:rofiulwahyudi@gmail.com
}

\begin{abstract}
This study aims to determine the suitability of annual reports that reflect Islamic Corporate Identity and its influence on the performance of islamic bank. Design of this research is causal research with quantitative approach. Samples of this research are Bank Muamalat Indonesia and Bank Syariah Mandiri. Secondary data were obtained from annual reports from 2010 to 2012 as data collection techniques of this study. To analyze the data of Islamic Corporate Identity (ICI), the writer used a checklist of eight dimensions disclosed in annual reports of Islamic banks. The analysis technique used is the panel data regression analysis using eviews. The results of this study can be concluded that the disclosure of Islamic Corporate Identity (ICI) in the annual report of Bank Muamalat Indonesia and Bank Mandiri Syariah compliant reporting standards that reflect the Islamic ideal Corporate Identity (ICI) with an average value of $85 \%$. Islamic Corporate Identity (ICI) has influence on a CAR of $85.30 \%$, amounting to $92.67 \%$ FDR, NPF amounting to 95.2\%. Islamic Corporate Identity (ICI) has no effect on ROA, ROE and ROA.
\end{abstract}

Keywords: Islamic Bank, Islamic Corporate Identity, Performance

\section{Abstrak}

Perbankan Syariah merupakan representasi dari gelombang baru perusahaan yang mempunyai fungsi sosial sejajar pentingnya dengan mencari keuntungan (profit oriented). Salah satu fungsi sosial tersebut adalah zakat. Apabila perusahaan berorientasi pada zakat berarti sama halnya dengan berorientasi pada kinerja perusahaan secara keseluruhan, sebab untuk meningkatkan kemampuan zakat perusahaan harus terlebih dahulu 
meningkatkan kinerja perusahaan. Penelitian ini bertujuan untuk mengetahui pengaruh kinerja keuangan terhadap zakat perbankan syariah. Jenis penelitian ini merupakan penelitian terapan. Variabel Independen yang digunakan adalah kinerja keuangan diproksi dengan Financing to Deposit Ratio (FDR), Non Performing Financing (NPF), Return on Asset (ROA) dan Biaya Operasional terhadap Pendapatan Operasional (BO/PO), variabel dependen berupa zakat perbankan syariah. Populasi dalam penelitian ini adalah perbankan syariah, baik Bank Umum Syariah (BUS) maupun Unit Usaha Syariah (UUS) di Indonesia. Metode penentuan sampel dengan metode purposive sampling, dan berdasarkan kriteria jumlah sampel yaitu tiga BUS dan dua UUS periode tahun 2007-2012. Data penelitian merupakan data sekunder berupa laporan tahunan dan laporan keuangan yang diperoleh masing-masing dari annual report. Pengujian hipotesis penelitian digunakan teknik analisis regresi dengan data panel dengan alat bantu aplikasi eviews versi 6. Hasil penelitian menunjukkan bahwa: 1) Financing to Deposit Ratio (FDR) berpengaruh signifikan terhadap zakat, 2) Non Performing Financing (NPF) tidak berpengaruh signifikan terhadap zakat, 3) Return on Asset (ROA) tidak berpengaruh signifikan terhadap zakat, 4) Biaya Operasional terhadap Pendapatan Operasional (BO/PO) berpengaruh signifikan terhadap zakat. Berdasarkan hasil penelitian menunjukkan bahwa kinerja keuangan memiliki pengaruh yang berbeda pada setiap rasio yang diwakili terhadap zakat perbankan syariah. Hal ini ditunjukkan oleh adanya pengaruh FDR dan $\mathrm{BO} / \mathrm{PO}$ terhadap zakat perbankan syariah, sedangkan ROA dan NPF tidak berpengaruh terhadap zakat. Namun, variabel independen secara simultan berpengaruh signifikan terhadap variabel dependen. Sehingga disimpulkan bahwa untuk mencapai kinerja perusahaan yang tinggi dibutuhkan kemampuan untuk meningkatkan zakat.

Kata Kunci: Perbankan syariah, Kinerja Keuangan, Zakat

\section{Pendahuluan}

Identitas perusahaan lebih dikenal atau lebih popular dengan nama Corporate Identity (Identitas Perusahaan) adalah istilah yang pertama kali dipopulerkan oleh J.Gordon Lippincott dan Walter P. Margulies, insinyur sipil di era 1940-an bergerak dibidang, image dan marketing (Parhusip, 2011 :2). Identitas perusahaan adalah kombinasi logo, komposisi warna, tipografi atau bentuk huruf, bentuk seragam pegawai, bentuk khas peralatan, kendaraan dinas, fasilitas ataupun pelayanan yang diberikan dari suatu perusahaan dan sebagainya, yang semuanya mengidentifikasikan keunikan 
dan keberadaan suatu perusahaan (Kotler, 2001: 882).

Identitas perusahaan tidak hanya memiliki keunikan organisasi dilihat dari atribut visual, tetapi atribut non-fisik seperti perilaku dari staf dan pengelola organisasi. Menurut (Cenadi,1999: 4-5), beberapa bentuk aplikasi corporate identity yang sering digunakan perusahaan berupa, antara lain: business stationery (kop surat, amplop, memo, kartu nama,forms, bon, dan lain-lain), advertising, poster, brosur dan katalog, signage system, gedung perusahaan, annual report (laporan tahunan), newsletter (buletin perusahaan) dan kendaraan perusahaan.

Anggoro (2000: 280) mendifinisikan identitas perusahaan (corporate identity) sebagai suatu cara atau suatu hal yang memungkinkan perusahaan dikenal dan dibedakan dari perusahaan-perusahaan lainnya. Selanjutnya, identitas perusahaan (corporate identity) diciptakan melalui suatu desain khusus yang meliputi hal-hal unik atau khas tentang perusahaan yang bersangkutan secara fisik. Menurut Berrone (2007: 3) identitas perusahaan (corporate identity) mendapat respon dari praktisi dan akademisi, karena diyakini memiliki pengaruh positif terhadap reputasi perusahaan. Hal ini juga ditegaskan Roberts dan Dowling (2002: 1), bahwa reputasi yang baik akan menjamin kemampuan perusahaan dalam mempertahankan keuntungan dari waktu ke waktu, sehingga berimplikasi pada peningkatan kinerja perusahaan.

Identitas perusahaan (corporate identity) merupakan salah satu elemen penting dalam strategi komunikasi perusahaan, dimana hal tersebut mencerminkan rencana perusahaan yang matang. Identitas perusahaan (corporate identity) yang baik sejalan dengan strategi dan rencana perusahaan, sehingga berimplikasi pada terciptanya reputasi perusahaan, yaitu persepsi masyarakat terhadap perusahaan atau produknya.

Bank Syariah adalah bank bebas bunga yang didasarkan pada konsep mudharabah dan musyarakah, yaitu konsep profit and loss sharing (PLS) atau bagi hasil (Saeed, 2004: xiv). Konsep ini mengantarkan kepada kinerja Bank Syariah di Indonesia tumbuh dan berkembang dengan pencapaian yang baik. Namun perkembangan dan pertumbuhan yang pesat bank syariah tersebut, masyarakat masih kurang jelas akan identitas bank syariah. Ciri khas bank syariah harus dimunculkan dan diaplikasikan ke dalam identitas 
perusahaan Islam yakni Islamic Corporate Identity (ICI). Haniffa dan Hudaib (2007: 2), telah mengkomunikasikan identitas perusahaan Islam, Islamic Corporate Identity (ICI) pada Bank Syariah dengan menggunakan laporan tahunan (annual report).

Haniffa dan Hudaib (2007: 3) berpendapat bahwa pelaporan laporan tahunan (annual report) yang di dalamnya memuat nilai-nilai Islam, seperti: antara lain: 1) filosofi dan nilai yang mendasari Bank Syariah, 2) penyediaan produk dan jasa bebas bunga, 3) pembatasan Bank Syariah kepada transaksitransaksi yang diperbolehkan syariah, 4) fokus kepada tujuan pengembangan dan sosial, 5) tunduk kepada tinjauan Dewan Pengawas Syariah (DPS).

Pengungkapan identitas perusahaan Islam, Islamic Corporate Identity (ICI) melalui laporan tahunan (annual report) seharusnya memberikan pengaruh yang baik bagi reputasi perbankan syariah. Alessandri (2001: 173) berargumen bahwa visi dan misi perusahaan akan mempengaruhi identitas yang tampak dari reputasi perusahaan yang selanjutnya akan mempengaruhi kinerja perusahaan. Dengan kata lain, reputasi yang baik akan menjamin kemampuan perusahaan dalam mempertahankan kinerja dari waktu ke waktu. Selain itu, tantangan untuk menjaga reputasi identitas perusahaan Islam (Islamic Corporate Identity) di masyarakat menjadi alasan Bank Syariah melakukan laporan tahunan yang berbeda dengan perbankan konvensional.

Berdasarkan latar belakang di atas maka rumusan masalah pada penelitian ini adalah: Bagaimana kesesuaian pengungkapan laporan tahunan Bank Umum Syariah yang mencerminkan Islamic Corporate Identity? Apakah Islamic Corporate Indentity berpengaruh terhadap Kinerja Bank Umum Syariah?

\section{Kerangka Teori}

\section{Corporate Identity}

Menurut kamus bahasa Inggris, the holt intermediate dictionary of english dijelaskan arti kata sebagai berikut : Corporate $=$ of or by a group of individualis acting as a single body yang bermakna keterpaduan, badan usaha atau lembaga. The British Standard's Institute dalam Balmer (2007) mendefinisikan corporate identity:Articulation of what an organisatoin is, 
what stands for, whait it does and the way it goes about its business (especially the way it relates to its stakeholders and the environment).

Identitas perusahaan adalah kombinasi logo, komposisi warna, tipografi atau bentuk huruf, bentuk seragam pegawai, bentuk khas peralatan, kendaraan dinas, fasilitas ataupun pelayanan yang diberikan dari suatu perusahaan dan sebagainya, yang semuanya mengidentifikasikan keunikan dan keberadaan suatu perusahaan (Kotler, 2001: 339).

\section{Islamic Corporate Identity}

Identitas merupakan kenyataan dan keunikan dari sebuah perusahaan yang membedakannya dari perusahaan lainnya. Reputasi perusahaan yang selaras dengan tanggung jawab sosial perusahaan harus didasarkan pada konsep-konsep syariat Islam (Abdullah, 2009: 9). Berdasarkan prinsip-prinsip Islam, transaksi-transaksi bisnis tidak pernah dipisahkan dari tujuan-tujuan moral dalam masyarakat (Muhamad, 2009: 2).

Perusahaan Islami yang memiliki kekhasan atau identitas (core corporate) tentunya akan dibangun bersamaaan dengan corporate culture yang menjadi sebuah jiwa, yang berguna mencapai visi misi perusahaan sehingga perusahaan mampu dikondisikan baik secara iklim kerja maupun impact positif yang ditimbulkan lainnya kepada pihak eksternal (Adityangga, 2010: 4).

Secara keseluruhan, semua kegiatan perusahaan Islami tidak terlepas dari triangel yang meliputi akidah, syariah dan akhlak. Hal tersebut dinyatakan Adityangga (2010: 4), bahwa komitmen perusahaan Islami pada aspek akidah sebagai landasan filosofi, idealisme dan paradigma yang dimilikinya, sedangkan syariah yang melatarbelakangi rule of ethic dari bisnis itu sendiri. sedangkan akhlak sebagai cerminan goal tindakan yang nantinya akan dievaluasi, dipertanggungjawabkan atas amanah dan pola perilaku yang telah dilakukan.

Haniffa dan Hudaib (2007: 3) mengkomunikasikan laporan tahunan (annual report) perbankan syariah yang dianggap sebagai Islamic Corporate Identity, dengan delapan dimensi yang merupakan penjabaran dari lima prinsip utama yang membedakan bank syariah dari bank konvensional dengan komposisi yang tidak sama untuk masing-masingnya: 1) filosofi dan 
nilai yang mendasari bank syariah; 2) penyediaan produk dan jasa bebas bunga; 3) pembatasan bank syariah kepada transaksi-transaksi yang diperbolehkan syariah; 4) fokus kepada tujuan pengembangan dan sosial; dan 5) tunduk kepada tinjauan Dewan Pengawas Syariah (DPS).

Dimensi pertama dan kedua (pernyataan visi misi dan informasi lengkap tentang dewan komisaris dan manajemen puncak) merupakan penjabaran jadi prinsip pertama filosofi dan nilai yang mendasari bank syariah. Dimensi ketiga, produk dan layanan merupakan turunan dari dua prinsip berikutnya yaitu penyediaan produk dan jasa bebas bunga serta pembatasan Bank Syariah kepada transaksi-transaksi yang diperbolehkan syariah. Empat dimensi berikutnya yaitu dimensi zakat, sedekah dan pinjaman kebajikan; dimensi komitmen terhadap karyawan; dimensi komitmen terhadap debitur; dimensi komitmen kepada masyarakat diturunkan dari prinsip fokus pada tujuan pengembangan dan sosial. Sedangkan dimensi terakhir yang membahas Dewan Pengawas Syariah adalah penjabaran dari prinsip tinjauan oleh Dewan Pengawas Syariah.

\section{Kinerja Bank Syariah}

Kinerja bank secara umum merupakan gambaran prestasi yang dicapai oleh bank dalam operasionalnya. Pengukuran kinerja Perbankan dalam hal ini menggunakan kinerja keuangan. Kinerja keuangan merupakan gambaran kondisi keuangan bank pada suatu periode tertentu baik mencakup aspek penghimpunan dana maupun penyaluran dananya (Kusumo, 2008: 111). Kinerja keuangan perbankan dapat dinilai dengan pendekatan analisa rasio keuangan.

Rasio merupakan alat ukur yang digunakan bank untuk menganalisis laporan keuangan. Rasio menggambarkan suatu hubungan atau pertimbangan antara suatu jumlah tertentu dengan jumlah yang lain. Analisis rasio keuangan berguna sebagai analisis intern bagi manajemen perusahaan untuk mengetahui hasil finansial yang telah dicapai guna perencanaan yang akan datang dan juga untuk analisis intern bagi kreditor dan investor untuk menetukan kebijakan pemberian kredit dan penanaman modal suatu perusahaan (Bahtiar Usman, 2003). 
Pengaruh Islamic Corporate Identity (ICI) terhadap Kinerja Bank Syariah...

Dengan menggunakan alat analisa berupa rasio keuangan dapat menjelaskan dan memberikan gambaran kepada penganalisa tentang baik atau buruknya keadaan atau posisi keuangan suatu perusahaan dari suatu periode ke periode berikutnya. Menurut peraturan Bank Indonesia Nomor 3/30/DPNP tanggal 14 Desember 2001 (www.bi.go.id). Rasio-rasio kinerja Bank Syariah adalah sebagai berikut: Rasio Permodalan, Rasio Aktiva Produktif, Rasio Profitabilitas, Rasio Likuiditas dan Rasio Kepatuhan (Compliance).

\section{Studi Pustaka}

Penelitian yang dilakukan Roszaini Haniffa dan Mohammad Hudaib (2007) melakukan penelitian tentang perbedaan antara identitas perbankan syariah dengan perbankan konvensional tentang Exploring the Ethical sIdentity of Islamic Banks via Communication in Annual Reports. Indikator penelitian ini mencakup empat dimensi yaitu: Pengungkapan visi dan misi perusahaan, komitmen kepada masyarakat, kontribusi dan pengelolaan zakat, amal dan baik hati pinjaman dan informasi mengenai manajemen puncak. Untuk mengukur indikator tersebut, Haniffa dan Hudaib menggunakan pendekatan yang disebut Indeks Identity Etis (EII). Adapun hasil penelitian disebutkan bahwa terdapat perbedaan karakteristik perbankan syariah dibandingkan dengan perbankan konvensional.

Nidaul Uswah Prasetyaningsih dan Nugroho Iman Prakosa (2010) juga melakukan penelitian tentang Islamic Corporate Identity dalam Praktek Pengungkapan Laporan Tahunan Bank Syariah. Instrumen penelitian ini merupakan replikasi atas instrumen Haniffa dan Hudaib (2007) dengan sampel tiga bank syariah yang ada di Indonesia untuk periode 2008. Adapun hasil penelitian menunjukkan praktek pengungkapan mengenai dana Zakat, Infak dan Shodaqah serta dana kebajikan dalam laporan tahunan ketiga bank syariah tersebut masih minim. Namun secara umum pengungkapan laporan tahunan ketiga bank syariah sudah mendekati pelaporan ideal yang mencerminkan Islamic Corporate Identity.

Mohamad, Bakar dan Adzrieman (2007) telah melakukan penelitian hubungan antara identitas perusahaan dan reputasi perusahaan pada 
Perguruan Tinggi Malaysia. Indikator penelitian untuk identitas perusahaan yaitu, komunikasi dan visual yang gambar, perilaku budaya perusahaan dan kondisi pasar dan indikator reputasi yaitu, etika dirasakan, pekerja, kinerja keuangan, kepemimpinan, manajemen, sosial kewajiban, pelanggan fokus, kualitas, kehandalan dan daya tarik emosional. Responden pada penelitian ini adalah mahasiswa kelas matrikulasi dengan jumlah 500 mahasiswa. Adapun hasil penelitian ini menunjukkan bahwa ada hubungan langsung antara identitas perusahaan dan reputasi perusahaan.

Fitri (2008), telah melakukan penelitian tentang pengaruh variabelvariabel pembentukan reputasi perusahaan terhadap kinerja perusahaan. Variabel yang digunakan pada penelitian ini yaitu; corporate performance, corporate reputation, corporate governance, CEO reputation dan accouting measurement. Data yang digunakan adalah data sekunder berupa laporan keuangan tahunan perusahaan publik yang termasuk dalam indeks LQ 45 yang terdaftar di Bursa Efek Indonesia (BEI). Populasi pada penelitian ini adalah seluruh perusahaan publik yang termasuk dalam indeks LQ-45 yang terdaftar di Bursa Efek Indonesia (BEI) per Februari 2007 - Januari 2008 dengan sampel 73 perusahaan. Adapun hasil penelitian ini ditemukan bahwa indikator-indikator dari variabel corporate performance dan corporate governance tidak mempengaruhi kinerja. Indikator-indikator dari variabel $C E O$ reputation memiliki hubungan positif namun tidak signifikan dengan kinerja perusahaan, dan indikator-indikator dari variabel accouting measurement signifikan mempengaruhi kinerja perusahaan.

Penelitian Ahmad Zaki dan Mahfud Sholihin (2010) tentang pengaruh Corporate Ethical Identity terhadap kinerja keuangan. Adapun hasil penelitian ini menunjukkan bahwa dari tujuh indikator, tiga di antaranya berada di atas rata-rata. Selanjutnya, studi ini menunjukkan menunjukkan hubungan negatif Corporate Ethical Identity terhadap kinerja keuangan adalah dimensi visi dan misi pernyataan, Dewan Komisaris dan manajemen puncak, zakat, amal, pinjaman kebajikan dan DPS. Di sisi lain, pengungkapan produk dan layanan serta karyawan mempengaruhi kinerja dengan positif.

Berdasarkan penelitian-penelitian yang ada, bahwa Identitas perusahaan (corporate identity) yang baik sejalan dengan strategi dan rencana perusahaan, sehingga berimplikasi pada terciptanya reputasi perusahaan. 
Reputasi perusahaan yang dikelola dengan baik akan menjamin kemampuan perusahaan dalam mempertahankan keuntungan dari waktu ke waktu, sehingga berimplikasi pada peningkatan kinerja perusahaan. Sehingga identitas perusahaan (Corporate Identity) dapat mempengaruhi kinerja.

Berikut adalah kerangka fikir dari penelitian ini:

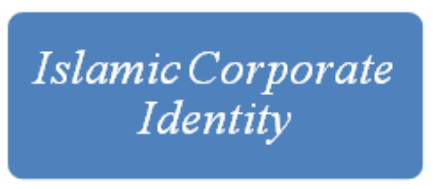

\title{
Kinerja Bank
}

\author{
Gambar 1 \\ Kerangka Fikir \\ Pengaruh Islamic Corporate Identity terhadap Kinerja
}

Berdasarkan kerangka pikir yang telah diformulasikan, maka hipotesis yang diajukan dalam penelitian ini adalah adanya pengaruh Islamic Corporate Identity terhadap kinerja bank syariah.

\section{Metode Penelitian}

Penelitian ini menggunakan desain penelitian kausal, karena berupaya mengetahui hubungan yang bersifat sebab akibat antara dua variabel atau lebih yaitu pengaruh Islamic Corporate Identity terhadap kinerja bank syariah. Desain penelitian kausal memasukkan dan menguji variabel independen yaitu Islamic Corporate Identity dan kinerja sebagai variabel dependen dengan proksi rasio Return On Asset (ROA), Return On Equity (ROE), rasio BOPO, rasio Financing Deposit Ratio (FDR), Capital Adequacy Ratio (CAR) rasio Non Performing Financing (NPF).

Populasi pada penelitian ini adalah seluruh bank syariah yang beroperasi di Indonesia periode penelitian. Pemilihan sampel penelitian ini didasarkan pada metode nonprobability sampling tepatnya metode purposive sampling. Sampel pada penelitian ini adalah Bank Muamalat Indonesia (BMI) dan Bank Syariah Mandiri (BSM) periode 2010-2012.

Teknik analisis data dilakukan dengan beberapa tahapan, adapun tahap-tahap penghitungan dan pengolahan data sebagai berikut: 
a. Menghitung indeks Islamic Corporate Identity, dengan cara pemberian skor untuk setiap item pengungkapan dilakukan secara dikotomis.

b. Perhitungan kinerja bank menggunakan rasio-rasio keuangan yang telah ada di dalam laporan keuangan.

c. Membuat analisis dengan data panel. Penggunaan model regresi data panel yang ada dalam penelitian ini dimaksudkan agar dalam menganalisis pengaruh Islamic Corporate Identity terhadap kinerja bank syariah. Langkah-langkah analisis dengan data panel sebagai berikut:

1) Estimasi Model Data Panel (common effect, fixed effect, dan random effect)

2) Uji Kesesuaian Model menggunakan, a) Chow test adalah pengujian untuk memilih apakah model yang digunakan Pooled Least Square Model atau Fixed Effect Model, b) Hausman test adalah pengujian statistik sebagai dasar pertimbangan kita dalam memilih apakah menggunakan Fixed Effect Model atau Random Effect Model, c) LM test (The Breush - Pagan LM Test) digunakan sebagai dasar pertimbangan stastisik dalam memilih model random effect dan pooled least square.

3) Uji Hipotesis dengan melakukan uji t statistik dan analisis koefisien determinasi $\left(\mathrm{R}^{2}\right)$.

\section{Pembahasan}

Hasil penelitian menunjukkan bahwa Bank Muamalat Indonesia (BMI) dan Bank Syariah Mandiri (BSM) telah sesuai dan telah mendekati standar pelaporan dalam pengungkapan delapan dimensi yang mencerminkan Islamic Corporate Identity. Hasil penelitian tentang pengaruh Islamic Corporate Identity terhadap kinerja bank syariah dijelaskan berikut ini:

\section{Pengaruh Islamic Corporate Identity terhadap BOPO}

Hasil penelitian mengenai Islamic Corporate Identity terhadap BOPO ditemukan bahwa ICI tidak berpengaruh terhadap BOPO yang ditunjukkan oleh sig. $t$ sebesar 0,596472 lebih besar dari 0,05. Hasil tersebut menunjukan bahwa informasi mengenai tingkat beban operasional dan tingkat pendapatan 
Pengaruh Islamic Corporate Identity (ICI) terhadap Kinerja Bank Syariah...

operasional yang diungkapkan dalam laporan tahunan bank syariah, tidak menunjukkan adanya hubungan Islamic corporate identity terhadap BOPO. Hal tersebut dikarenakan informasi-informasi seperti remunerasi komisaris, DPS dan karyawan yang diungkapkan ICI tidak secara langsung mempengaruhi kinerja rasio BOPO.

Berdasarkan data laporan tahunan, rasio BOPO BMI sebesar 87,38\% pada tahun $2010,85,25 \%$ dan $84,48 \%$ pada tahun 2011 dan 2012. Sedangkan rasio BOPO BSM pada tahun 2010 sebesar 74,97\% dan 73,00\%, 76,44\% pada tahun 2011 dan 2012.

\section{Pengaruh Islamic Corporate Identity terhadap Capital Adequacy Ratio}

Hasil penelitian mengenai Islamic Corporate Identity terhadap CAR ditemukan bahwa ICI berpengaruh terhadap CAR yang ditunjukkan oleh sig. $t$ sebesar 0.008545 lebih kecil dari 0,05 . Hasil tersebut menunjukan bahwa dengan adanya informasi rasio kecukupan modal yang mencerminkan kesehatan bank pada laporan tahunan (annual report), deposan dapat menilai pihak bank syariah dapat mengelola rasio CAR dengan baik. Bank yang memiliki tingkat kecukupan modal yang baik berarti menunjukan indikator sebagai bank yang sehat. Sebagai bank yang sehat tentu hal ini membangun kepercayaan masyarakat untuk menggunakan produk dan jasa baik sebagai debitur maupun kreditur.

Dengan demikian, adanya informasi rasio CAR yang baik, bank syariah dapat dinilai mampu menjaga kepercayaan masyarakat dimana secara teori bank merupakan lembaga kepercayaan, sehingga hal ini merupakan cerminan dari Islamic corporate identity yang diungkapkan melalui laporan tahunan (annual report).

Berdasarkan data laporan tahunan, rasio CAR BMI sebesar 13,26\% pada tahun $2010,12,01 \%$ dan $11,57 \%$ pada tahun 2011 dan 2012. Sedangkan rasio CAR BSM pada tahun 2010 sebesar 10,64\%, 14,57\% dan 13,82\% pada tahun 2011 dan 2012. Hasil tersebut menunjukan bahwa BMI dan BSM sudah memenuhi batas standar minimum rasio CAR yang telah ditetapkan oleh bank Indonesia sebesar 8\%., sehingga dapat disimpulkan kedua bank tersebut memiliki tingkat kecukupan modal yang baik. 


\section{Pengaruh Islamic Corporate Identity terhadap Financing Deposit Ratio}

Hasil penelitian pengaruh Islamic Corporate Identity terhadap FDR ditemukan bahwa ICI berpengaruh terhadap rasio FDR yang ditunjukkan sig. t sebesar 0,002070 lebih kecil dari 0,05. Hasil tersebut menunjukan dengan adanya informasi, bahwa bank syariah mampu menjalankan fungsi intemediasi dengan baik ditunjukkan oleh rasio FDR yang optimal. Selain itu, intermediasi bank syariah juga dibatasi pada aktivitas investasi dan pembiayaan yang sesuai dengan prinsip syariah. Fungsi intermediasi yang optimal yang juga diikuti oleh aktivitas investasi dan pembiayaan yang sesuai dengan prinsip syariah merupakan cerminan dari Islamic corporate identity yang diungkapkan melalui laporan tahunan (annual report).

Berdasarkan data laporan tahunan, rasio FDR BMI sebesar 91,52\% pada tahun 2010, 85,18\% dan 95,15\% pada tahun 2011 dan 2012. Sedangkan rasio FDR BSM pada tahun 2010 sebesar 82,54\%, 86,54\% dan 94,40\% pada tahun 2011 dan 2012. Berdasarkan data tersebut di atas, selama periode 2010 hingga tahun 2012, kondisi likuiditas BMI dan BSM relatif terjaga sebagaimana tercermin dari tingkat FDR. Dengan kata lain, bank syariah mampu menjalankan fungsi intermediasi pada tingkat yang optimal sebagaimana tercermin dari posisi FDR sebesar 100,\% atau sedikit lebih tinggi dari posisi di tahun sebelumnya. Tingginya pertumbuhan pembiayaan juga dibarengi dengan penerapan prinsip kehati-hatian secara baik. Hal ini menunjukkan bahwa fungsi intermediasi dilakukan secara optimal dimana peningkatan dana yang dihimpun dari masyarakat dapat disalurkan kembali kepada masyarakat dalam bentuk pembiayaan.

\section{Pengaruh Islamic Corporate Identity terhadap Non Performing Financing}

Hasil penelitian pengaruh Islamic Corporate Identity terhadap NPF ditemukan bahwa ICI berpengaruh terhadap rasio NPF yang ditunjukkan oleh sig. t sebesar 0,000878 lebih kecil 0.05. Hasil tersebut menjelaskan bahwa pengendalian NPF yang baik oleh bank syariah yang diungkapkan melalui laporan tahunan (annual report) menunjukkan adanya hubungan Islamic corporate identity terhadap rasio NPF. Hal tersebut sesuai dengan 
Pengaruh Islamic Corporate Identity (ICI) terhadap Kinerja Bank Syariah...

teori yang menyatakan bahwa NPF merupakan perbandingan pembiayaan bermasalah dibandingkan dengan total pembiayaan. Rendahnya tingkat NPF menunjukan bahwa bank syariah mampu menerapkan prinsip kehati-hatian (prudential banking) dalam penyaluran dana masyarakat dalam bentuk pembiayaan. Di sisi lain, rendahnya NPF menunjukkan kemampuan bank syariah mendapatkan kembali piutang sehingga hal ini mendorong pertumbuhan pendapatan yang pada akhirnya mencerminkan perusahaan Islam (Islamic Corporate Identity) yang mampu mengelola dana masyarakat dengan prinsip amanah.

Berdasarkan data laporan tahunan, BMI mampu mengendalikan rasio NPF secara baik yaitu sebesar 3,51\% pada tahun $2010,1,78 \%$ dan $1,81 \%$ pada tahun 2011 dan 2012. Sedangkan rasio NPF BSM selama tahun 2010 hingga tahun 2012, berhasil dikendalikan sebesar 3,52\%, 2,42\% dan 2,82\%.

\section{Pengaruh Islamic corporate identity terhadap Return On Asset}

Hasil penelitian pengaruh Islamic Corporate Identity terhadap ROA ditemukan bahwa ICI tidak berpengaruh terhadap rasio ROA yang ditunjukkan sig. $\mathrm{t}$ sebesar 0,514165 lebih besar dari 0.05 . Hasil tersebut menunjukan bahwa dengan adanya informasi melalui laporan tahunan bank syariah tidak adanya hubungan Islamic corporate identity terhadap ROA.

Hasil penelitian di atas mendukung temuan Zaki dan Sholihin (2010) tentang pengaruh Corporate Ethical Identity terhadap kinerja keuangan yang diproksi dengan rasio ROA yang menunjukkan tidak adanya hubungan antara Corporate Ethical Identity dengan kinerja keuangan yaitu berupa rasio ROA.

Rasio ROA adalah kemampuan bank syariah dalam memperoleh return / pendapatan dari pengelolaan aset. Semakin tinggi rasio ROA semakin baik bagi bank syariah karena akan meningkatkan daya tarik bagi investor untuk menanamkan dananya dalam rangka memperoleh return / pendapatan yang optimal.

Berdasarkan data laporan tahunan, rasio ROA BMI yaitu sebesar 1,36\% pada tahun 2010, 1,52\% dan 1,54\% pada tahun 2011 dan 2012. Sedangkan rasio ROA BSM selama tahun 2010 hingga tahun 2012 yaitu secara berurutan sebesar $2,21 \%, 1,95 \%$ dan $2,25 \%$. 


\section{Pengaruh Islamic corporate identity terhadap Return On Equity}

Hasil penelitian pengaruh Islamic Corporate Identity terhadap ROE ditemukan bahwa ICI tidak berpengaruh terhadap rasio ROE yang ditunjukkan oleh sig. $t$ sebesar 0,449343 lebih besar dari 0,05. Hasil tersebut menunjukan bahwa adanya informasi dalam laporan tahunan (annual report), tidak menunjukan adanya hubungan Islamic corporate identity terhadap rasio ROE.

Hal tersebut d ikarenakan informasi return / pendapatan yang berasal dari modal pemegang saham yang dimasukan ke dalam pembiayaan yang diungkapkan dalam laporan tahunan merupakan faktor internal bank. Dengan kata lain, tidak adanya hubungan ICI terhadap ROE, dikarenakan rasio ROE merupakan indikator kepentingan para pemegang saham yang ditunjukkan oleh laba atas modal pemegang saham.

Rasio ROE adalah kemampuan bank syariah dalam memperoleh pendapatan yang didanai dari sebagian modal. Semakin besar rasio ROE maka makin besar kenaikan laba bersih bank yang bersangkutan, selanjutnya akan menaikan harga saham bank syariah dan semakin besar deviden yang diterima investor dan pemegang saham.

Berdasarkan data laporan tahunan, rasio ROE BMI yaitu sebesar 17,78\% pada tahun $2010,20,79 \%$ dan $29,16 \%$ pada tahun 2011 dan 2012. Sedangkan rasio ROE BSM selama tahun 2010 hingga tahun 2012 yaitu secara berurutan sebesar $63,54 \%, 64,84 \%$ dan $68,09 \%$.

\section{Penut up}

Peneliti menyadari bahwa keterbatasan utama penelitian ini masih terdapat pada jumlah data yang digunakan. Penggunaan data panel yang lebih banyak dan pengukuran dengan jenis corporate identity lainnya diharapkan mampu menghasilkan hasil yang lebih menggambarkan kenyataan. Selain itu, dibutuhkan pengukuran kinerja lainnya diharapkan dapat menangkap pengaruh tersebut secara lebih jelas.

Berdasarkan hasil penelitian dan pembahasan yang telah dikemukakan pada bab sebelumnya, maka dapat ditarik kesimpulan sebagai berikut: 
a. Pengungkapan laporan tahunan Bank Umum Syariah yaitu BMI dan BSM pada tahun 2010-2012 telah sesuai yang mencerminkan Islamic Corporate Identity.

b. Pengaruh Islamic Corporate Identity (ICI) terhadap kinerja keuangan ditemukan dua hasil yang berbeda:

c. Islamic Corporate Identity (ICI) berpengaruh terhadap kinerja keuangan diwakili oleh rasio CAR, FDR dan NPF.

d. Islamic Corporate Identity (ICI) tidak berpengaruh terhadap kinerja keuangan diwakili oleh rasio ROA, ROE dan BOPO.

\section{Daftar pustaka}

Adityangga, Krishna. 2010. Membangun Perusahaan Islam dengan Manajemen Budaya Perusahaan Islami. Jakarta: PT. Raja Grafindo Persada.

Anggoro, Linggar. 2000. Teori Aplikasi Kehumasan serta Aplikasinya di Indonesia. Jakarta: Bumi Aksara.

Abdullah, Zulhamri. 2009. "Beyond Corporate Image: Projecting International Reputation Management as a New Theoretical Approach in a Transitional Country." Journal of Economics and Management.

Alessandri, S.W. 2001. "Modeling Corporate Identity: A Concept Explication and Theoretical Explanation", Corporate Communications: An International Journal, 6 (4). Diakses pada tanggal 19 Maret 2013

Balmer, J. M. 2007. "Identity Based Views of the Corporation: Insights from Corporate Identity, Organisational Identity, Social Identity, Visual Identity, Corporate Brands and Corporate Image." Working Paper No. 07/07.

Bahtiar, Usman. "Analisis Rasio Keuangan Dalam Memprediksi Perubahan Laba Pada Bank-bank di Indonesia." Media Riset Bisnis dan Manajemen. Vol.3. No.1. April 2003.

Berrone, P.,J. Surroca dan J.A. Tribo, "Corporate Ethical Identity as a Determinant of Firm Performance: A Test of the Mediating Role of Stakeholder Satisfaction”, Journal of Business Ethics, 76, 2007. Diakses pada tanggal 18 Maret 2013

Cenadi, Chirstine Suharto. 1999. "Corporat Identity, Sejarah dan Aplikasinya. Journal Desain Komunikasi Visual.” NIRMANA Vol. 
1, No. 2, $71-78 \mathrm{Http} / /$ puslit.petra.ac.id/journals/design/. Diakses pada tanggal 22 Maret 2013

Fitri. 2008. "Pengaruh Variabel-variabel Pembentukan Reputasi Perusahaan terhadap Kinerja Perusahaan (Studi Empiris pada Indeks LQ 45 Tahun 2007)." Skripsi. Fakultas Ilmu Sosial dan Ilmu Politik Departemen Ilmu Administrasi Program Sarjana Universitas Indonesia. Diakses pada tanggal 20 Maret 2013

Haniffa, R. M. dan M. A. Hudaib. 2007. "Exploring the Ethical Identity of Islamic Banks via Communication in Annual Reports." Journal of Business Ethics. Diakses pada tanggal 10 Maret 2013.

Kotler, Philip. 2001.Manajemen Pemasaran. Jakarta: PT. Indeks

Kusumo, Yunanto Adi. 2008. "Analisis Kinerja Keuangan Bank Syariah Mandiri Periode 2002 - 2007 (dengan Pendekatan PBINo. 9/1/PBI/ 2007)." Jurnal Ekonomi Islam. Vol. II, No. 1. Diakses pada tanggal 20 Maret 2013.

Mohamad, Bahtiar. Hassan Abu Bakar dan Nik Adzrieman Abdul Rahman. "Relationship between Corporate Identity and Corporate Reputation: A Case of a Malaysian Higher Education Sector." Jurnal Manajemen Pemasaran, Vol. 2, No. 2, Oktober 2007: 81-89. Diakses pada tanggal 18 Maret 2013

Muhammad, Rifqi. 2009. "Studi Evaluatif terhadap Laporan Perbankan Syariah." JAAI Volume 13 No. 2, 189-209. Diakses pada tanggal 10 April 2013.

Muhamad. 2008. Metodologi Penelitian Ekonomi Islam: Pendekatan Kuantitatif. Jakarta: Rajagrafindo Persada

Prasetyaningsih, Nidaul Uswah dan Nugroho Imam Prakosa. 2010. "Islamic Corporate Identity dalam Praktek Pengungkapan Laporan Tahunan Bank Syariah.” Best Papers: Forum Riset Perbankan Syariah II

Peraturan Bank Indonesia Nomor 3/30/DPNP tanggal 14 Desember 2001

Roberts, P. W. dan G. R. Dowling. 2002. "Corporate Reputation and Sustained Superior Financial Performance." Strategic Management Journal, 23. http//www.interscience.wiley.com. Diakses pada tanggal 22 Maret 2013.

Saeed, Abdullah.2004. "Menyoal Bank Syariah:Kritik atas Interpretasi Bung Bank Kaum Neo-Revivalis." Paramadina: Jakarta

Zaki, Ahmad dan Mahfud Sholihin. 2010. "Pengaruh Corporate Ethical Identity terhadap Kinerja Keuangan: Studi Kasus pada Bank Syariah di Negara-Negara Asia." Journal of Islamic Economic. Diakses pada tanggal 25 Maret 2013 